\title{
19. GLACIAL-INTERGLACIAL SEA-SURFACE TEMPERATURE RECORD INFERRED FROM ALKENONE UNSATURATION INDICES, SITE 893, SANTA BARBARA BASIN'
}

\author{
Timothy D. Herbert, ${ }^{2}$ Memorie Yasuda, ${ }^{2}$ and Christopher Burnett ${ }^{2}$
}

\begin{abstract}
Samples from Ocean Drilling Program Hole 893A were analyzed for paleotemperatures by determining the " $\mathrm{Uk}_{37}$ " unsaturation index at about $3 \mathrm{k} . \mathrm{y}$. resolution over the past $162 \mathrm{ka}$. Values of the unsaturation index at Hole 893A range from 0.415 to 0.696 , corresponding to a total range in estimated paleotemperature of $8^{\circ} \mathrm{C}$. Most of the variance is paced by the $4 \mathrm{I} \mathrm{k.y.} \mathrm{obli-}$ quity cycle, although 100 k.y. eccentricity and 21 k.y. precessional components are present as well. The pattern of alkenone unsaturation indices over time is quite different from that produced by planktonic foraminiferal paleoclimatic proxies. We conclude that the alkenone record approximates the history of sea-surface temperature in the Santa Barbara Basin over the time period studied. Alkenone data suggest that Santa Barbara Basin sea-surface temperatures exceeded present values by about $4^{\circ}$ during oxygen isotope Stage $5 \mathrm{e}$. The Younger Dryas event may be represented as a $3^{\circ}$ cooling that spanned several k.y. The predominance of the obliquity cycle in inferred glacial-interglacial changes in sea-surface temperature most likely reflects a real divergence of North Pacific sea-surface temperature from the classical picture of glacial-interglacial change based on oxygen isotope analyses. Alkenone abundances in the sediment vary by nearly two orders of magnitude. High abundances coincide with laminated facies, suggesting that oxygen content of basinal waters plays an important role in the preservation of these compounds.
\end{abstract}

\section{INTRODUCTION}

Santa Barbara Basin is situated at the juncture of two important surface current systems. It is strongly influenced by the California Current, which is the descending limb of North Pacific cyclonic circulation. The California Current brings cold and nutrient-enriched waters to Santa Barbara Basin. Santa Barbara Basin also marks the northern extension of the coast-hugging California Countercurrent, which flows northward to Point Conception, bringing warmer tropical waters to the Southern California coast seasonally. Although it is known that waters along the Southern Californian margin show temperature anomalies following El Niño-Southern Oscillation events (Simpson, 1983; Lynn and Simpson, 1987; Pares-Sierra and O'Brien, 1989), little is known of sea-surface temperature (SST) variations on longer time scales (but see a radiolarian SST reconstruction for the last 8 k.y. by Pisias, 1978). The purpose of this investigation was to determine the nature of glacial to interglacial SST changes using the " $\mathrm{U}^{\mathrm{k}}{ }_{37}$ " organic paleothermometer.

Organic paleotemperature estimates can be derived from the unsaturation index of $\mathrm{C}_{37}$ alkenones, which are compounds secreted exclusively by prymnesiophyte algae, and principally by the coccolithophorid prymnesiophyte E. huxleyi (Volkman et al., 1980; Marlow et al., 1984). As shown by Brassell et al. (1986) and Prahl and co-workers (Prahl and Wakeham, 1987; Prahl et al., 1988), the unsaturation index varies linearly with the water temperature in which the alkenone-synthesizing organisms grow. Because their production is limited to the photic zone, the environmental temperature controlling alkenone unsaturation generally approximates SST at the time of production. Although alkenones are degraded in the water column and sediments, degradation does not appear to alter the relative proportions of the $\mathrm{C}_{37}$ ketones that define the unsaturation index (Prahl et al., 1989a).

'Kennett. J.P., Baldauf, J.G.. and Lyle. M. (Eds.), 1995. Proc, ODP. Sci. Results. 146 (P1. 2): College Station, TX (Ocean Drilling Program).

Geological Research Division. Scripps Institution of Oceanography. La Jolla, CA 92093-0215. U.S.A
Alkenone SST reconstructions are a useful complement to stable isotopic and micropaleontological methods of environmental reconstruction. Unlike $\delta^{18} \mathrm{O}$ measurements, which have a strong imprint of global ice volume changes (c.f. Shackleton, 1967) and regional salinity variations, the alkenone unsaturation index responds almost entirely to temperature. The temperature information is apparently preserved in the face of degradation, which is not true for micropaleontological methods of temperature reconstruction (see Thompson, 1981). A number of studies have now characterized glacial-interglacial temperature changes by the alkenone method (Brassell et al., 1986; Eglinton et al., 1992; Jasper and Gagosian, 1989; Lyle et al., 1992; Poynter et al., 1989; Schneider et al., 1995). Only two reports have been published that extend alkenone paleotemperature estimates in the Pacific Ocean to the last interglacial; these both come from sediments collected near the equator (Farrimond et al., 1990; Lyle et al., 1992).

Any reconstruction based on a biological index may have biases, and the alkenones are no exception. The sedimentary record may reflect a weighted average of the conditions of maximum water column production of alkenones, or of maximal preservation in the underlying sediment. Alkenone paleotemperatures could be biased toward unusual "bloom" events, or toward a small fraction of the year. However, if we look to high-resolution $\mathrm{U}_{37}^{\mathrm{k}}$ records recovered from Santa Barbara Basin, the picture is encouraging. Kennedy and Brassell (1992) measured alkenone paleotemperatures in sediments spanning the years 1915-1986, and found that ENSO signals (of a magnitude of $1{ }^{\circ} \mathrm{C}$ or less) are preserved by the unsaturation index. Their time series does not show abrupt, large magnitude shifts in estimated SST, as would be the case if the sedimentary record of the $\mathrm{Uk}_{37}$ index was overly sensitive to short, unrepresentative temperature conditions.

The work of Kennedy and Brassell (1992) and our own unpublished data do show that high frequency (decadal to century) alkenone unsaturation variations corresponding to SST anomalies on the order of $1^{\circ}-2^{\circ} \mathrm{C}$ have characterized Santa Barbara Basin over the past century. The possibility of similar variations must be considered when evaluating glacial to interglacial SST estimates by $\mathrm{U}^{\mathrm{k}}{ }_{37}$ measurements on discrete samples. Individual samples obtained from 
Hole 893A span I cm of sediment and an average of 5-10 years of deposition. The average spacing of our samples is $3 \mathrm{k} . \mathrm{y}$. (time scale of Kennett and Ingram, this volume). Such sampling is adequate to capture SST variations on the time scale of the earth's orbital cycles (c.f. Imbrie et al., 1984), but may be aliased to some degree by undersampling higher frequency variations in SST.

\section{METHODS}

Lipids were extracted following the method of Kennedy (1992) and compound classes isolated for gas chromatography following the procedure of McCaffrey (1990). Two to $5 \mathrm{~g}$ of wet sediment were extracted by ultrasonication using a sequence of three solvents: $100 \%$ methanol, 2: I methylene chloride:methanol (twice), and 100\% methylene chloride. The extracts were combined in a separatory funnel and the methylene chloride fraction was collected and dried down by rotary evaporation.

The lipid extract was separated into compound classes by silica gel column chromatography. The columns were prepared by heating the silica gel (100-200 mesh, Malinckrodt) for $24 \mathrm{hr}$ at $130^{\circ} \mathrm{C}$, and activating the gel by the addition of $5 \%$ (by weight) water. Seven $g$ of silica gel was slurried into a $35 \mathrm{~cm}$ column ( $1 \mathrm{~cm}$ i.d.). Lipid extracts were loaded onto silica gel with hexane. Compound classes were separated by a sequence of solvents $(20 \mathrm{~mL}$ each): $100 \%$ hexane, $25 \%$ toluene in hexane, $50 \%$ toluene in hexane, $5 \%$ ethyl acetate in hexane, $10 \%$ ethyl acetate in hexane, $15 \%$ ethyl acetate in hexane, and $20 \%$ ethyl acetate in hexane. Alkenones eluted in the fifth fraction of this scheme. Chromatograms of fractions 4 and 6 showed minor peaks ( $5 \%$ or less of alkenone area) that would have co-eluted with the alkenones, but lacked the diagnostic $\mathrm{C}_{37}, \mathrm{C}_{38}$, and $\mathrm{C}_{39}$ structure of the alkenone biomarkers. The silica gel procedure almost completely separated $\mathrm{C}_{37}$ ketones from the diunsaturated $\mathrm{C}_{36}$ methyl ester that typically elutes on the shoulder of the $\mathrm{C}_{37: 2}$ alkenone peak of untreated samples.

Relative alkenone abundances were measured by GC/FID (Hewlett-Packard 5890 GC) using on-column injection. An HP-5 capillary column $(50 \mathrm{~m}, 0.2 \mathrm{~mm}$ i.d., $0.11 \mu \mathrm{m}$ film thickness) was used for analysis. The temperature ramp was set to $6^{\circ} \mathrm{C} / \mathrm{min}$ to $180^{\circ} \mathrm{C}$ and $2^{\circ} \mathrm{C} / \mathrm{min}$ to $310^{\circ} \mathrm{C}$, followed by a $30-\mathrm{min}$ isothermal stage at $310^{\circ} \mathrm{C}$. With this temperature program, the $\mathrm{C}_{37: 2}$ and $\mathrm{C}_{37: 3}$ compounds eluted with nearly complete peak separation over a gentle, steadily increasing baseline. Compound identifications and purity were verified on selected samples by GC/MS at Indiana University (courtesy of A. Schimmelmann and S. Brassell). Alkenone abundances were estimated by calibrating FID response to an internal standard, a $\mathrm{C}_{36}$ alkane, added to each extract prior to injection into the GC.

Representative GC/FID chromatograms over the region of interest are shown in Figure 1. Peak areas of the $\mathrm{C}_{37: 2}$ and $\mathrm{C}_{37: 3}$ alkenones were calculated following baseline subtraction using Hewlett-Packard ChemStation software. All samples were run in duplicate. The average difference between replicates was $0.004 \mathrm{U}^{\mathrm{k}}{ }_{37}$ units, corresponding to a paleotemperature uncertainty of less than $0.15^{\circ} \mathrm{C}$ (note that this error refers to analytical uncertainty, not to uncertainty introduced by calibration functions of $\mathrm{U}^{\mathrm{k}}{ }_{37}$ to temperature).

\section{RESULTS}

The present sampling gives a record of alkenone concentrations, expressed as mass per gram of dried sediment, and alkenone unsaturation indices over the last one and one-half major glacial cycles at a resolution of about 3 k.y. at Santa Barbara Basin. Data are listed in Table 1 and displayed in Figures 2 and 3. Conversion of alkenone unsaturation indices to paleotemperature follows the calibration of Prahl et al. (1988) using the $\mathrm{U}^{\mathrm{k}}{ }_{37}^{\prime}$ index. Figure 2 shows the correla- tion between alkenone-derived SST estimates and the benthic $\delta^{18} \mathrm{O}$ curve of Kennett (this volume), arranged on the time scale of Ingram and Kennett (this volume) and Kennett (this volume). The positions of the Holocene Optimum, Younger Dryas, and Last Glacial maximum are also indicated in Figure 2.

The total amplitude of SST changes over the past $160 \mathrm{ka}$ at Santa Barbara Basin are inferred to be about $8^{\circ} \mathrm{C}$. Four prominent minima occur at sub-bottom depths of about 43,92, 140, and $170 \mathrm{~m}$, or at about $28,70,110$, and $145 \mathrm{ka}$. The warmest temperatures recorded by the alkenone method occur at 143.79 and $147.9 \mathrm{~m}$ sub-bottom. These coincide with marine oxygen isotope Stage $5 \mathrm{e}$, at about $122 \mathrm{ka}$, when alkenone estimates suggest that SST was about $4^{\circ} \mathrm{C}$ warmer than present-day.

Although there are some similarities to the classical $\delta^{18} \mathrm{O}$ expression of glacial-interglacial climate change, the $\mathrm{U}^{\mathrm{k}}{ }_{37}$ record is dominated to a much greater extent by a circa $40 \mathrm{k} . \mathrm{y}$. component, and to a much lower degree by the circa 100 and 20 k.y. components so evident in $\delta^{18} O$ curves (c.f. Hays et al., 1976) (Fig. 4). Spectral analysis of short (relative to the periods of the Earth's orbital cycles believed to pace most glacial-interglacial climate change) records must be treated cautiously. Nevertheless, the frequency spectrum of the $\mathrm{U}_{37}^{\mathrm{k}}$ series (Ingram and Kennett [this volume] time scale) shows that most of the variance is at a period of slightly longer than 40 k.y. (Fig. 5). Maximal spectral amplitude occurs at 45, 21, and 16 k.y., and the Ftest measure of signal-to-noise following the Thomson (1985) multiple-taper method finds line frequencies at 113, 37, 19 k.y. at above $90 \%$ confidence. We view these results as consistent with an orbital imprint dominated by the 41 k.y. cycle of obliquity, but with significant components at the other important "Milankovitch" frequencies as well.

Alkenone paleotemperature estimates for Santa Barbara Basin show a number of features unusual to late Pleistocene marine climatic records. The dominance of circa $41 \mathrm{k} . \mathrm{y}$. energy mentioned above is one. A second important observation is that the period associated with the Last Glacial Maximum has a small inferred temperature contrast with the latest Holocene. Termination II, the transition to the previous interglacial, has a similar structure to that of the Last Glacial Maximum, with temperatures inferred to rise well before the onset of oxygen isotope Stage 5e.

The pattern of alkenone unsaturation indices recorded at Hole 893A does not closely match conventional foraminiferal paleotemperature proxies. This discrepancy will be considered at more length in the following section.

The major maxima and minima of the Santa Barbara alkenone temperature record are paced by the Earth's obliquity cycle, as indicated by the obliquity reference curve above our SST reconstruction in Figure 4. Pronounced positive $\mathrm{U}^{\mathrm{k}}{ }_{37}$ anomalies match the climatic optima paced by the 100 k.y. cycle of glaciation, but most of the SST amplitude belongs to the obliquity frequency band. Extremes in alkenone-derived SST lag obliquity forcing by at most a few k.y. Smaller-amplitude maxima and minima appear paced by the Earth's precessional cycle, in phase with the Northern Hemisphere precessional index. Still higher-frequency fluctuations of more than $1^{\circ} \mathrm{C}$ may be present. Our data suggest that a significant cooling occurred at about the same time as the Younger Dryas event so well characterized in the North Atlantic (Ruddiman and McIntyre, 1981; Broecker et al., 1988). Other short-term events may not be resolved by our average sample interval of 3 k.y.

Alkenone abundances, expressed as concentration per gram of dried sediment, display a rather different pattern from the unsaturation index (Fig. 3). $\mathrm{C}_{37}$ ketones vary in concentration by nearly two orders of magnitude at Hole $893 \mathrm{~A}$. The abundance pattern shows peaks that generally coincide with interglacial stages. A lag of about 5 k.y. between the benthic oxygen isotope record of Kennett (leading) and $\mathrm{C}_{37}$ ketone concentration (lagging) seems maintained for the 162 ka record. A very close correspondence exists between alkenone con- 

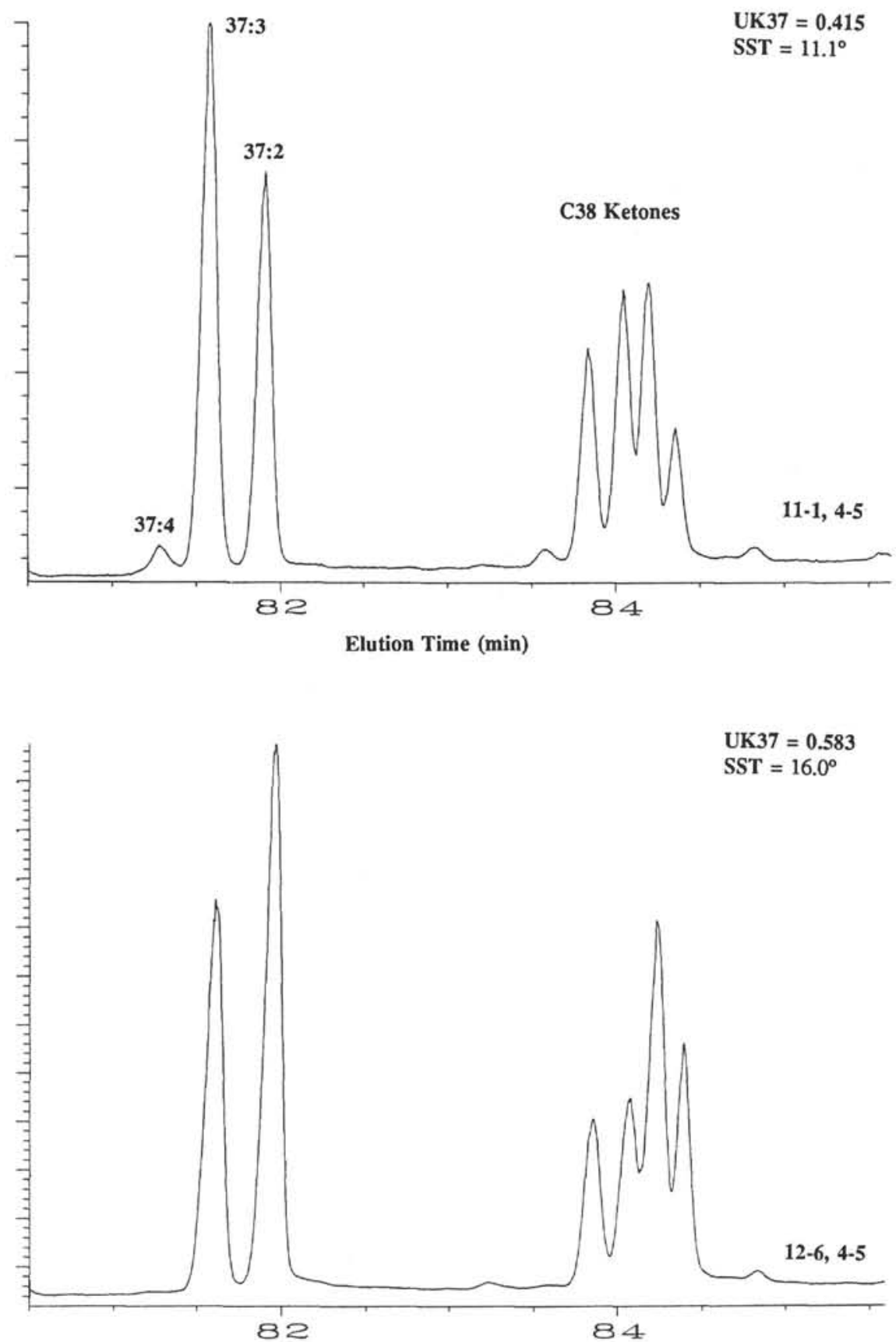

Figure 1. Representative chromatograms of the alkenone-containing region of Hole 893A samples. Upper panel shows chromatogram from Core 146-893A$11 \mathrm{H}-1,4-5 \mathrm{~cm}$; lower panel is chromatogram from Core 146-893A-12 H-6, 4-5 cm. Alkenone unsaturation index is calculated from peak areas of $\mathrm{C}_{37: 2}$ and $\mathrm{C}_{37: 3}$ ketones.

centration and the state of bioturbation of the sediments. All high values coincide with intervals of the core described as laminated; low values coincide with sections that are bioturbated or structureless.

\section{DISCUSSION}

We interpret the record of alkenone unsaturation indices listed in Table 1 and displayed in Figures 2, 3, and 4, to correspond closely to the history of mean annual SST at the location of Site 893. In this section we discuss some uncertainties associated with this conclusion, and compare our results with paleoclimatic indices from the same location. Some of these caveats can be addressed by looking to previous studies of the production and preservation of alkenone signals; others must be addressed by looking for internal consistency (or lack thereof) in our data set; some must await further studies.

Potential pitfalls include:

1. The data are not accurate reflections of alkenone unsaturation indices, or the $\mathrm{U}_{37}^{\mathrm{k}}$ index is unreliable as an SST proxy in the environment of Site 893. We believe that these objections are very unlikely. Analytical errors have been reported above, and 
Table 1. $C_{37}$ ketone concentrations and unsaturation indices, Hole 893A.

\begin{tabular}{|c|c|c|c|c|c|}
\hline $\begin{array}{l}\text { Core, section, } \\
\text { interval }(\mathrm{cm})\end{array}$ & $\begin{array}{l}\text { Depth } \\
\text { (mbsf) }\end{array}$ & $\begin{array}{l}\text { Age } \\
\text { (ka) }\end{array}$ & $\begin{array}{c}\mathrm{C}_{37} \text { conc. } \\
(\mu \mathrm{g} / \mathrm{g})\end{array}$ & $\mathrm{U}^{\mathrm{k}}{ }_{37}{ }^{\prime}$ & $\begin{array}{c}\text { Temperature } \\
\left({ }^{\circ} \mathrm{C}\right)\end{array}$ \\
\hline \multicolumn{6}{|l|}{$146-893 \mathrm{~A}-$} \\
\hline IH-1, 24-25 & 0.24 & 0.117 & 6.294 & 0.5464 & 14.9 \\
\hline $1 \mathrm{H}-1,75-76$ & 0.75 & 0.389 & 4.392 & 0.5692 & 15.6 \\
\hline $1 \mathrm{H}-1,125-126$ & 1.25 & 0.668 & 6.786 & 0.5606 & 15.3 \\
\hline IH-2, 25-26 & 1.73 & 0.943 & 6.773 & 0.5857 & 16.1 \\
\hline IH-2, 75-76 & 2.23 & 1.234 & 4.462 & 0.5638 & 15.4 \\
\hline $1 \mathrm{H}-2,125-126$ & 2.73 & 1.528 & 6.058 & 0.5344 & 14.6 \\
\hline $1 \mathrm{H}-3,24-25$ & 3.23 & 1.826 & 0.557 & 0.5672 & 15.5 \\
\hline $1 \mathrm{H}-3,75-76$ & 3.74 & 2.133 & 1.591 & 0.5686 & 15.6 \\
\hline $1 \mathrm{H}-3,125-126$ & 4.24 & 2.436 & 6.489 & 0.5181 & 14.1 \\
\hline $2 \mathrm{H}-1,149-150$ & 7.97 & 4.753 & 3.430 & 0.5300 & 14.4 \\
\hline $2 \mathrm{H}-4,99-100$ & 11.71 & 7.144 & 0.452 & 0.5468 & 14.9 \\
\hline $3 \mathrm{H}-1,0-1$ & 16 & 9.943 & 2.795 & 0.5540 & 15.1 \\
\hline $3 \mathrm{H}-3,97-98$ & 19.97 & 12.52 & 0.518 & 0.4730 & 12.8 \\
\hline $3 \mathrm{H}-6,50-51$ & 23.66 & 15.047 & 0.128 & 0.5855 & 16.1 \\
\hline $4 \mathrm{H}-2,102-103$ & 27.72 & 17.795 & 0.409 & 0.5582 & 15.3 \\
\hline $4 \mathrm{H}-5,52-53$ & 31.34 & 20.265 & 0.540 & 0.5131 & 13.9 \\
\hline $5 \mathrm{H}-1,99-100$ & 35.99 & 23.463 & 0.309 & 0.5194 & 14.1 \\
\hline $5 \mathrm{H}-4,50-51$ & 39.49 & 25.887 & 0.858 & 0.5258 & 14.3 \\
\hline $5 \mathrm{H}-7,0-1$ & 43.06 & 28.372 & 1.806 & 0.4152 & 11.1 \\
\hline $6 \mathrm{H}-3,50-51$ & 47.4 & 31.896 & 1.425 & 0.4562 & 12.3 \\
\hline $6 \mathrm{H}-60-1$ & 51.13 & 34.623 & 0.771 & 0.4956 & 13.4 \\
\hline $7 \mathrm{H}-3,42-43$ & 55.47 & 37.746 & 1.488 & 0.4363 & 11.7 \\
\hline $7 \mathrm{H}-6,142-143$ & 60.43 & 41.315 & 0.701 & 0.5085 & 13.8 \\
\hline $8 \mathrm{H}-2,16-17$ & 63.81 & 43.747 & 0.666 & 0.5079 & 13.8 \\
\hline $8 \mathrm{H}-3,132-133$ & 65.99 & 45.316 & 0.156 & 0.5072 & 13.8 \\
\hline $8 \mathrm{H}-6,79-80$ & 69.47 & 47.82 & 1.289 & 0.5334 & 14.5 \\
\hline $9 \mathrm{H}-3,0-1$ & 75.55 & 52.4 & 1.201 & 0.5348 & 14.6 \\
\hline $9 \mathrm{H}-5,100-101$ & 79.12 & 55.411 & 1.274 & 0.4278 & 11.4 \\
\hline $10 \mathrm{H}-2,3-4$ & 83.9 & 59.442 & 0.425 & 0.4895 & 13.2 \\
\hline $10 \mathrm{H}-4,102-103$ & 87.93 & 62.841 & 1.374 & 0.4806 & 13.0 \\
\hline $11 \mathrm{H}-1,4-5$ & 92.02 & 66.635 & 1.739 & 0.4143 & 11.0 \\
\hline $11 \mathrm{H}-3,96-97$ & 95.85 & 70.727 & 0.417 & 0.4371 & 11.7 \\
\hline $11 \mathrm{H}-6,108-109$ & 99.49 & 74.617 & 4.760 & 0.4616 & 12.4 \\
\hline $12 \mathrm{H}-2,99-100$ & 103.72 & 79.136 & 4.270 & 0.4954 & 13.4 \\
\hline $12 \mathrm{H}-6,4-5$ & 107.67 & 83.357 & 3.391 & 0.5740 & 15.7 \\
\hline $13 \mathrm{H}-1,97-98$ & 111.66 & 87.62 & 1.351 & 0.4574 & 12.3 \\
\hline $13 \mathrm{H}-5,128-129$ & 116.37 & 90.017 & 0.582 & 0.4967 & 13.5 \\
\hline $13 \mathrm{H}-7$ 124-125 & 119.3 & 93.148 & 1.976 & 0.5788 & 15.9 \\
\hline $14 \mathrm{H}-3,49-50$ & 124.05 & 98.223 & 0.869 & 0.5501 & 15.0 \\
\hline $14 \mathrm{H}-7,107-108$ & 128 & 102.444 & 2.683 & 0.5426 & 14.8 \\
\hline $15 \mathrm{H}-2,49-50$ & 131.68 & 106.376 & 3.507 & 0.4980 & 13.3 \\
\hline $15 \mathrm{H}-5,0-1$ & 136.18 & 110.853 & 2.233 & 0.4158 & 11.1 \\
\hline $16 \mathrm{H}-1,49-50$ & 139.87 & 115.127 & 9.757 & 0.5927 & 16.3 \\
\hline $16 \mathrm{H}-4,0-1$ & 143.79 & 119.004 & 10.083 & 0.6624 & 18.3 \\
\hline $16 \mathrm{H}-6,99-100$ & 147.84 & 122.739 & 3.642 & 0.6887 & 19.1 \\
\hline $17 \mathrm{H}-3,0-1$ & 151.99 & 124.697 & 1.206 & 0.6244 & 17.2 \\
\hline $17 \mathrm{H}-5,98-99$ & 156.21 & 126.632 & 1.630 & 0.6052 & 16.7 \\
\hline $18 \mathrm{H}-2,1-2$ & 159.96 & 129.783 & 0.654 & 0.5441 & 14.9 \\
\hline $18 \mathrm{H}-4,101-102$ & 163.94 & 133.367 & 2.527 & 0.6012 & 16.5 \\
\hline $19 \mathrm{H}-1,1-2$ & 168.01 & 137.033 & 1.814 & 0.5237 & 14.3 \\
\hline $19 \mathrm{H}-3,99-100$ & 171.85 & 140.491 & 0.996 & 0.4509 & 12.1 \\
\hline $19 \mathrm{H}-6,48-49$ & 175.84 & 144.084 & 1.193 & 0.4576 & 12.3 \\
\hline $20 \mathrm{H}-2,102-103$ & 179.86 & 147.705 & 0.427 & 0.4579 & 12.3 \\
\hline $20 \mathrm{H}-5,49-50$ & 183.74 & 151.199 & 0.961 & 0.4669 & 12.6 \\
\hline $21 \mathrm{H}-1,99-100$ & 187.84 & 154.892 & 1.300 & 0.5326 & 14.5 \\
\hline $21 \mathrm{H}-4,89-90$ & 191.96 & 158.602 & 0.912 & 0.4706 & 12.7 \\
\hline $21 \mathrm{H}-6,112-113$ & 195.25 & 161.565 & 1.367 & 0.6162 & 17.0 \\
\hline
\end{tabular}

Note: Depths referred to are void-corrected meters below seafloor.

are very small compared to the magnitude of paleotemperature anomalies inferred. Analyses of $\mathrm{U}_{37}^{\mathrm{k}}$ over the historical period (Kennedy and Brassell, 1992; and Herbert et al., unpubl. data) show a good correspondence between SSTs inferred by the organic proxy and measured surface water temperatures in the Santa Barbara Basin. Thus, there is no reason to suggest a priori that the alkenone paleotemperature technique should not work well to reconstruct SST at Santa Barbara Basin on Glacial-Interglacial time scales. Within the data set reported here there is no suggestion of abrupt offsets in the time series presented in Figures 2-4 that might indicate regions of questionable data. In fact, most of the $U^{k}{ }_{37}$ values fall closely in line with adjacent measurements, and maxima and minima reach very similar values downcore. For example, the glacial SST minima are almost identically estimated at about $11^{\circ} \mathrm{C}$. Likewise, the high correlation of alkenone unsaturation indices with the obliquity cycle indicates that a strong signal runs

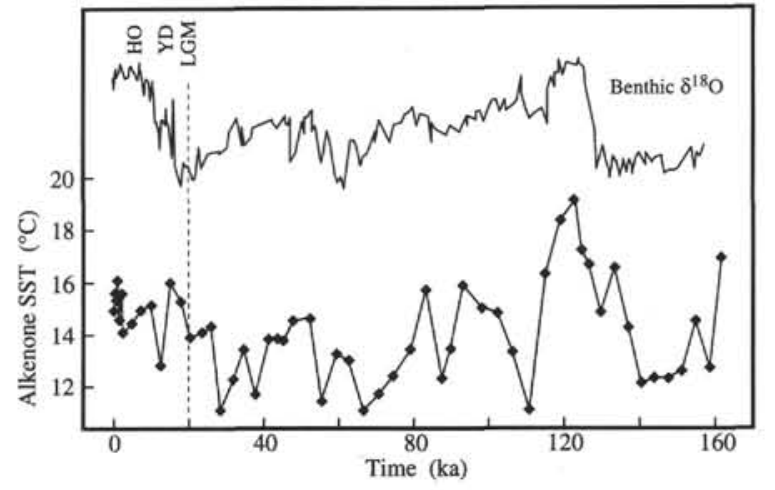

Figure 2. SST estimated by the alkenone unsaturation index vs. time. The upper curve is the benthic $\delta^{18} \mathrm{O}$ curve of Kennett (this volume). $\mathrm{HO}=$ Holocene Optimum, YD = Younger Dryas, LGM = Last Glacial Maximum.

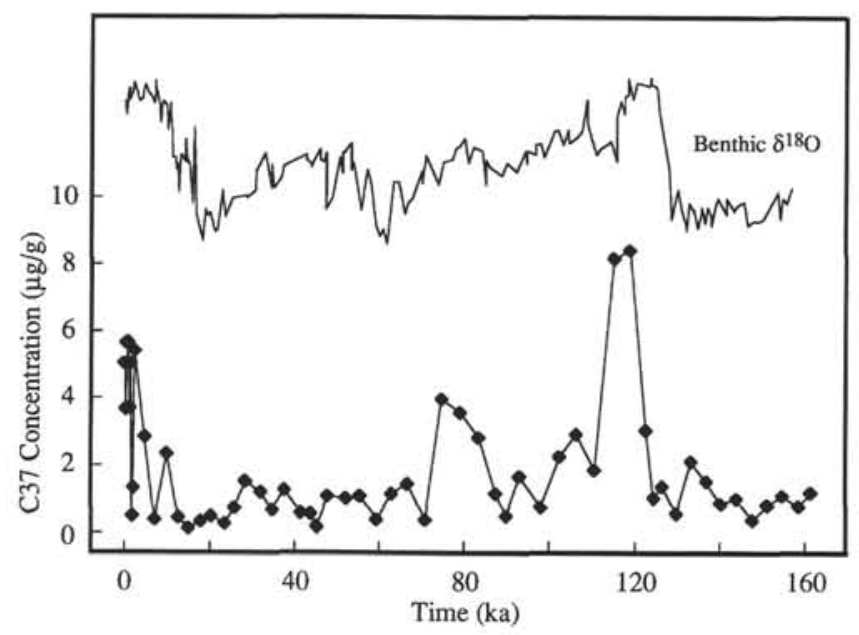

Figure 3. Alkenone abundance (per unit dry mass) vs. time at Hole 893A.

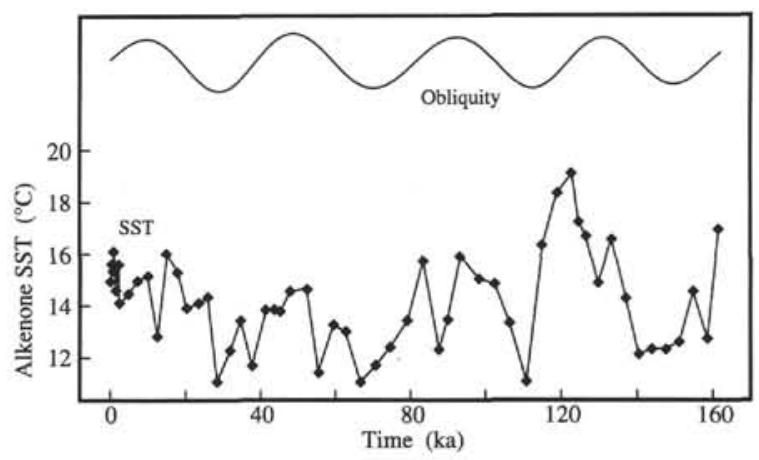

Figure 4. Obliquity curve superimposed on alkenone paleotemperature estimates from Hole 893A. Note that the two curves are almost exactly in phase.

through our reconstruction, regardless of its eventual paleoceanographic significance.

2. The $\mathrm{U}^{\mathrm{k}}{ }_{37}$ ratio may be biased by preservational artifacts in the Santa Barbara Basin sediments. There is no question that alkenones may be strongly degraded in the water column (Conte et al., 1992) and during early diagenesis (Prahl et al., 1989a, b; 


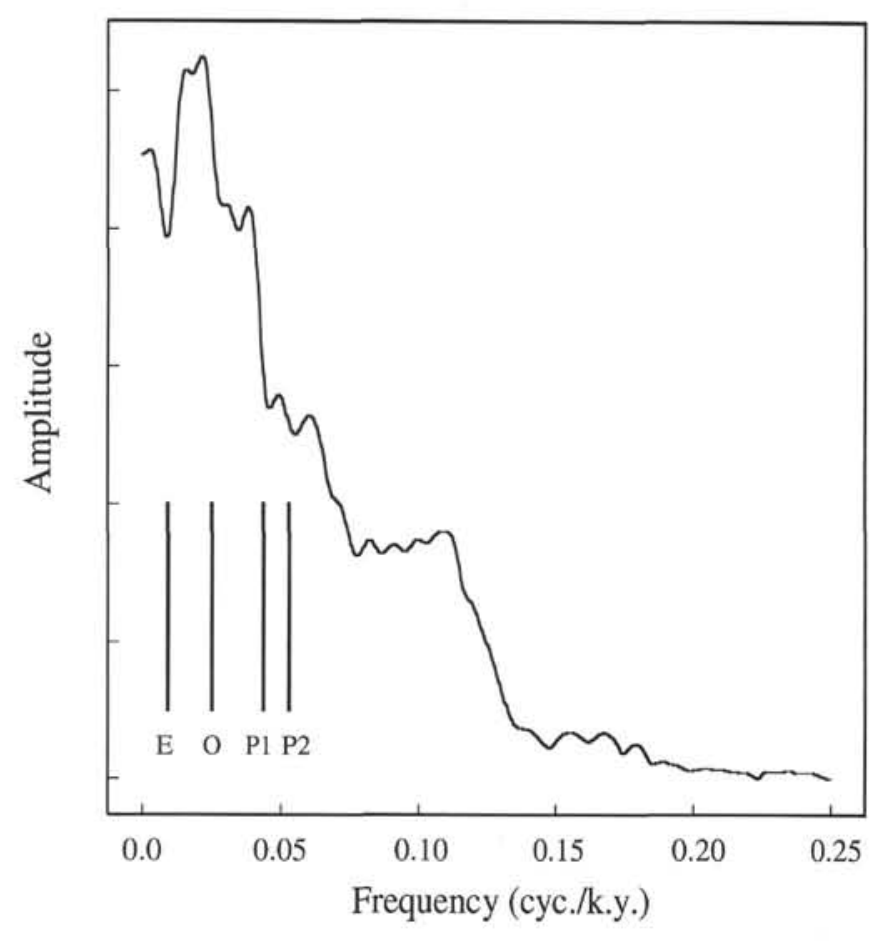

Figure 5. Amplitude spectrum of alkenone paleotemperature time series. Positions of spectral lines corresponding to major orbital frequencies labelled: $\mathrm{E}=109 \mathrm{k} . \mathrm{y}$. eccentricity cycle, $\mathrm{O}=41 \mathrm{k} . \mathrm{y}$. obliquity cycle, $\mathrm{Pl}=23$ k.y. component of precession, $\mathrm{P} 2=19 \mathrm{k} . \mathrm{y}$. component of precession.

Sun and Wakeham, 1994). Previous work has established that these processes do not measurably alter the unsaturation index of alkenones (Prahl et al., 1989a, Conte et al., 1992).

However, studies on the relative lability of long-chained alkenones apply to oxic sediments, and it is possible that the diagenetic conditions of the strongly sulfate-reducing Santa Barbara Basin sediments present special difficulties to the use of the organic paleotemperature proxy. In particular, it is possible that active sulfate reduction leads to the reaction of sulfur with many organic compounds (J. Kennedy, pers. comm., 1994). Such reactions would present a problem to the use of the $U^{k}$ index only if they significantly discriminate between the $\mathrm{C}_{37: 2}$ and $\mathrm{C}_{37.3}$ ketones. The most intense zone of sulfate reduction and the degradation of alkenones in present-day anoxic sediments is in the upper few centimeters of the sediment column (c.f. Kennedy and Brassell, 1992; McCaffrey, 1990; Sun and Wakeham, 1994). The data of Sun and Wakeham (1994) establishes that alkenones are in fact relatively resistant to degradation in the anoxic setting of Black Sea sediments. No offset in alkenone unsaturation indices within the sediment zone of rapid organic matter recycling has been observed to date; instead, alkenone paleotemperature results give very plausible SST's over the historical period at such active sulfate reduction environments as Santa Barbara Basin (Kennedy and Brassell, 1992) and the Peruvian margin (McCaffrey, 1990).

Within our data set, we find evidence that alkenone unsaturation indices are unlikely to have been offset by diagenesis. We looked at the correspondence of the $\mathrm{U}^{\mathrm{k}}{ }_{37}$ estimate to that of the similar unsaturation ratio of $\mathrm{C}_{38}$ ketones. From previous work, it is evident that the unsaturation of $\mathrm{C}_{38}$ ketones shows a temperature dependence to that of their $\mathrm{C}_{37}$ analogues (figures of Prahl et al., 1988; text and figures of Conte and Eglinton, 1993). Unfortunately, the $C_{38}$ ketones could not be completely

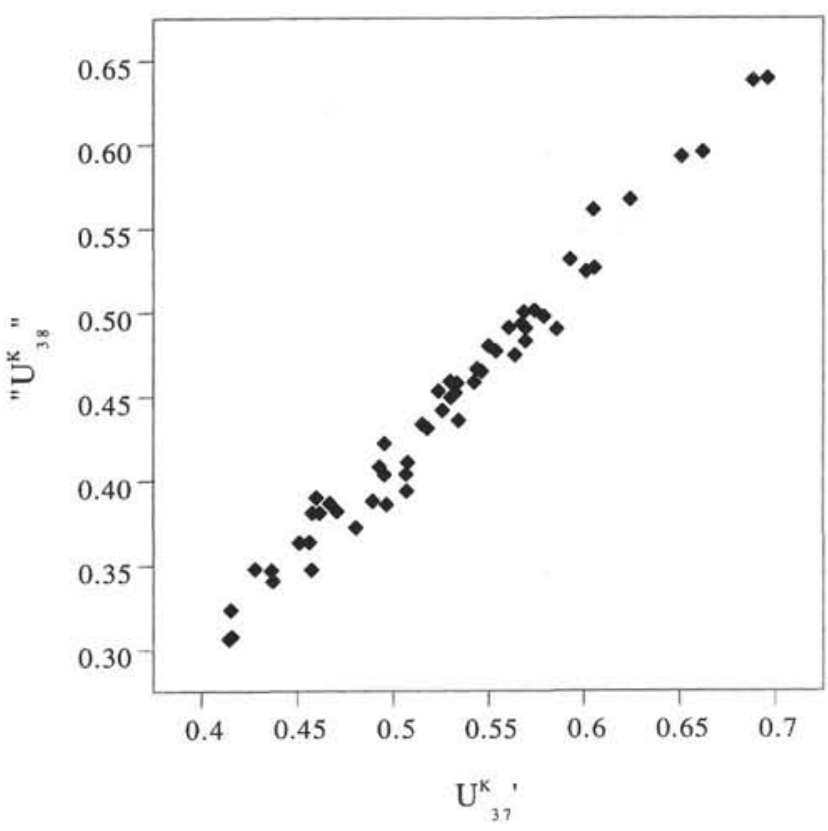

Figure 6. Correlation of unsaturation indices derived from $\mathrm{C}_{37 \mathrm{~m}}$ ketones to unsaturation of $\mathrm{C}_{3 \times}$ methyl ketones. Because the $\mathrm{C}_{3 \mathrm{~s}}$ ketones were not resolved to baseline, the $\mathrm{U}^{\mathrm{k}}{ }_{3 \mathrm{~m} \text { mi }}$ index is more dependent on analytical conditions than the $\mathrm{U}^{k}{ }_{y}^{\prime}$ index, and cannot be directly compared to previous literature.

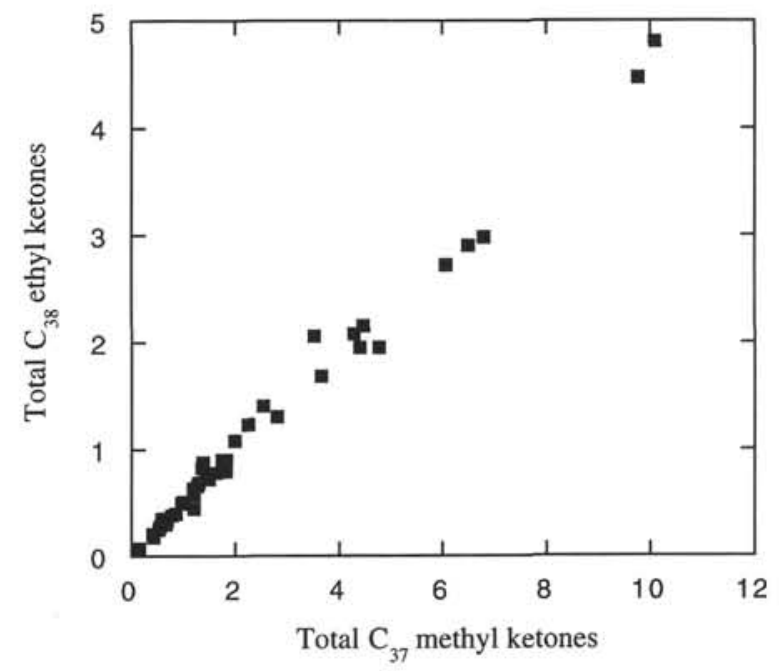

Figure 7. Abundance of $\mathrm{C}_{37}$ ketones compared to abundance of $\mathrm{C}_{3 \mathrm{x}}$ ethyl ketones. The tight correlation of these compounds argues for similar diagenetic behavior of prymnesiophyte biomarkers in Santa Barbara Basin sediments.

separated by our chromatographic procedures. The $\mathrm{U}^{\mathrm{k}}{ }_{38 \mathrm{me}}$ index (Conte and Eglinton, 1993) therefore cannot be measured as precisely or reproduced as well as the $\mathrm{U}^{\mathrm{k}}{ }_{37}$ measurement. Nevertheless, the correspondence between the two saturation indices is very close (Fig. 6). If diagenesis has affected the unsaturation of the $\mathrm{C}_{37}$ ketones significantly, it must therefore have affected the $C_{38}$ ketones in a precisely parallel manner. We find this unlikely. As an additional check, we plot the total $\mathrm{C}_{37}$ ketones against the abundance of $\mathrm{C}_{38}$ ethyl ketones (Fig. 7). We reason again that a significant diagenetic fractionation 
would show itself in offset or scatter of related prymnesiophyte compounds preserved in the sediment. Again, within the limits of measurement error, there is no evidence that diagenesis has strongly selected between ketones in the Santa Barbara setting.

3. The data accurately reflect growth temperatures when the $\mathrm{C}_{37}$ ketones were produced, but may suffer from ecological biases. Ecological uncertainties that could introduce artifacts in SST reconstruction include such factors as the average position in the water column of E. huxleyi, the dominant alkenone-producing prymnesiophyte, as a function of climatic regime, the possibility of unrepresentative E. huxleyi blooms, and possible shifts in the season of maximum alkenone synthesis and flux to the seafloor.

An additional complication could arise if there have been mixtures over time within the prymnesiophyte population of species or genetic variants contributing alkenones. It has been suggested that cold and warm morphotypes of E. huxleyi show different calibrations of unsaturation to growth temperature (Conte and Eglinton, 1993; Sikes and Volkman, 1993). We view the present evidence for regionally variable alkenone paleotemperature calibrations as less than conclusive, but acknowledge that this effect could bias paleotemperature determinations. Additionally, the alkenone record of Site 893 could contain variable contributions of the generally less abundant alkenone-synthesizing prymnesiophyte $G$. oceanica. The presence of a second, time-variable alkenone component with a different temperature dependence could also complicate the interpretation of glacial-interglacial temperature changes by the $\mathrm{U}^{\mathrm{k}}{ }_{37}$ unsaturation index. Although our data do not preclude this possibility, we believe that the tight correlation of $\mathrm{U}^{\mathrm{k}}{ }_{37}$ and $\mathrm{U}^{\mathrm{k}}{ }_{38 \mathrm{me}}$ indices would be unlikely if the alkenone data are compromised to a significant degree by differing contributions of species or morphotypes with different relations of unsaturation to temperature.

We view seasonal prymnesiophyte productivity variations as potentially the most problematic ecological bias that could affect the Santa Barbara alkenone record. If most production were to be concentrated in a short period of the year, then alkenone unsaturation indices may not be faithful recorders of average SSTs. For example, Prahl and co-workers (Prahl et al., 1993) have found from sediment trap and surface sediment samples that alkenone synthesis is maximal in the late winterearly spring bloom. The alkenone paleotemperature index found in sediments off the Oregon coast is therefore closer to winter than mean annual SST. Conte et al. (1992) also suggest that alkenones produced during spring blooms dominate the sedimentary record in the North Atlantic.

If a seasonal production bias were to shift with climatic regime, then the effect could be either to dampen or artificially increase the apparent glacial-interglacial temperature anomalies. For example, suppose that the Holocene sediment $\mathrm{U}^{\mathrm{k}}{ }_{37} \mathrm{ra}-$ tio dominantly reflects production during winter, but that most alkenones produced during glacial times were synthesized during summer blooms. The result would reduce the apparent SST anomaly from its true mean annual value. Conversely, a shift from a Holocene summer bloom-dominated ecology to one driven by peaks in winter production could bias the Holocene-Glacial temperature contrast estimated by $\mathrm{U}^{\mathrm{k}}{ }_{37}$ to overly large values.

It is difficult to rule out such potential biases in our $\mathrm{U}^{\mathrm{k}}{ }_{37}$ record. If they exist, then systematic ecological changes must have taken place to give a record paced predominantly by the 41 k.y. obliquity cycle. In this interpretation, the alkenone record would still be paleoceanographically significant, but could not be read as a faithful reflection of mean annual SST anomalies.

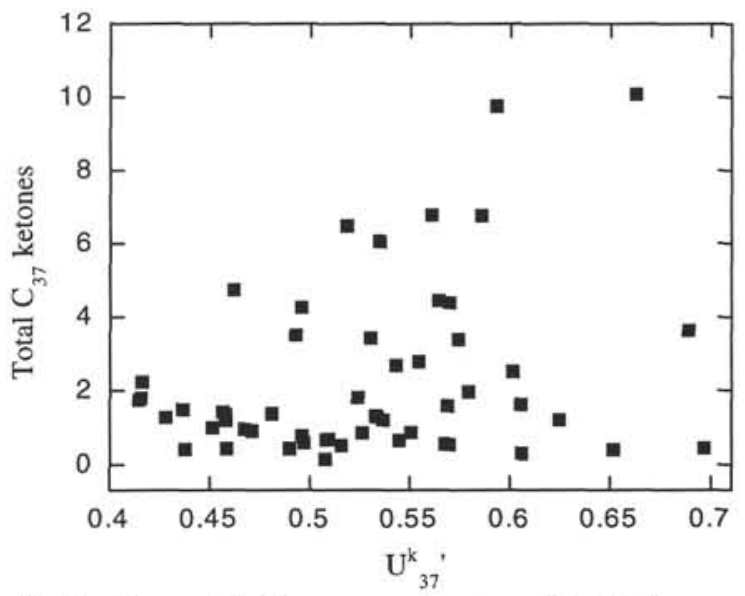

Figure 8. Abundance of $\mathrm{C}_{37}$ ketones as a function of the $\mathrm{U}_{37}{ }^{\prime}$ unsaturation index.

There is, however, no reason to believe that the alkenone record is seriously distorted by the record of short-term bloom events. If we look to the historical $\mathrm{Uk}_{37}$ record produced by Kennedy and Brassell (1992) (and to our own unpublished data), we see that the magnitude of alkenone yearly temperature anomalies is close to that actually measured in the surface waters of Santa Barbara Basin. Estimated paleotemperatures match rather closely the mean annual values determined for Santa Barbara SST. Furthermore, if we look to the relationship between alkenone abundance in the sediment and the unsaturation index (Fig. 8) we see no evidence of a strong dependance of production on temperature. This relationship is true whether one looks at annually-sampled data from the historical period (Kennedy and Brassell, 1992; Herbert et al., unpubl. data), or from the Site 893 record (Fig. 8). Alkenone abundance in the sediment cannot, of course, be directly interpreted in terms of water column flux. Nevertheless, the absence of any compelling temperature-abundance relationship is an argument that short, temperature-controlled bloom events do not dominate the $U^{k}{ }_{37}$ paleotemperature record in Santa Barbara Basin.

If we accept the $U^{k}{ }_{37}$ record from Site 893 as approximating the glacial-interglacial pattern of SST, then it becomes clear that the organic paleotemperature proxy has information to add not seen by other paleoclimatic proxies. We have noted above that the dominance of obliquity forcing in the $\mathrm{U}^{\mathrm{k}}{ }_{37}$ paleotemperature record is unlike most late Pleistocene climatic time series. This means that the $\mathrm{U}^{\mathrm{k}}{ }_{37}$ curve cannot be read, at least in this study area, as closely related to global ice volume as measured by benthic $\delta^{18} \mathrm{O}$ data. The organic proxy also does not resemble the $N$. pachyderma coiling direction record assembled at Site 893 by Kennett and Venz (this volume). Coiling directions are generally read as a paleotemperature proxy; their pattern leads Kennett and Venz (this volume) to infer cooling to $6^{\circ} \mathrm{C}$ during glacial maxima at the same time that the alkenone estimate suggests average temperatures of about $11^{\circ} \mathrm{C}$. Furthermore, the alkenone temperature estimates suggest SST warming well in advance of the Pleistocene/Holocene boundary, while the N. pachyderma coiling relation shows an abrupt shift at about $14 \mathrm{ka}$. The foraminiferal data suggest that warm temperatures have only occupied Santa Barbara Basin during the Holocene and oxygen isotope Stage 5e. Taken at face value, the $N$. pachyderma coiling direction data would suggest conditions of about $6^{\circ}$ during the generally warm oxygen isotope Stages $5 \mathrm{a}$ and $5 \mathrm{c}$. Alkenone data, in contrast, suggest that surface waters of the Santa Barbara Basin have frequently been nearly as warm as the present over the past $162 \mathrm{ka}$.

This discordance between two potential paleotemperature proxies makes it clear that further work will be needed to separate the various paleoclimatic signals stored in Santa Barbara Basin sediments. It may 
be that one or both proxies suffer from serious seasonal biases. It may become clear that foraminiferal assemblages and coiling ratios may be influenced significantly by factors other than SST, such as nutrient abundance and density/temperature gradients in the thermocline.

\section{CONCLUSIONS}

The alkenone reconstruction presented here paints a picture of large SST changes over the past $160 \mathrm{ka}$ at Santa Barbara Basin. We infer mean annual SST anomalies over this period of $+4^{\circ} \mathrm{C}$ and $-4^{\circ} \mathrm{C}$ relative to present-day conditions. It is useful to compare our alkenone record to CLIMAP's (1981) reconstruction of SST at the Last Glacial Maximum. CLIMAP produced winter and summer reconstructions of SST from statistical analysis of micropaleontological data (see Imbrie and Kipp, 1971; Pisias, 1978; CLIMAP, 1976, 1981; Moore et al., 1980). CLIMAP's reconstructed Last Glacial Maximum temperature anomaly near Santa Barbara Basin is about $-1^{\circ} \mathrm{C}$. Alkenone SST estimates are in good agreement: they indicate a cooling of about $1.5^{\circ}$ from present at $18 \mathrm{ka}$. However, the alkenone time series suggests that the pattern of glacial-interglacial SST change along the California coast may have been rather different from the CLIMAP model (Last Glacial Maximum coincides with greatest global cooling), and from alkenone paleotemperature time series obtained from Atlantic Ocean cores (Brassell et al., 1986; Jasper and Gagosian, 1989; Lehman et al, 1991). Apparently, maximum SST cooling at Santa Barbara Basin did not occur at the ice volume maximum recorded by oxygen isotopes at $18 \mathrm{ka}$. Rather, the strong obliquity forcing paced $3^{\circ}-4^{\circ} \mathrm{C}$ coolings at $41 \mathrm{k} . \mathrm{y}$. increments, the most recent being at $28 \mathrm{ka}$.

It is not clear how representative the alkenone SST record from Santa Barbara Basin will be of a larger region of the North Pacific. It must be remembered that SST in the California borderland basins may be affected by the competition between current systems, and that temperature anomalies may be influenced by migrating "fronts" between northerly and southerly-flowing waters. However, Pisias' (1978) analysis of the historical correlation of Santa Barbara Basin SST anomalies with those of a regional $1^{\circ}$ grid off California and Baja California showed overwhelmingly positive correlations between Santa Barbara Basin and regional temperature deviations. There are also indications from other study locations in the North Pacific of the strong obliquity signal in glacial-interglacial SST anomalies. Morley et al. (1987) find obliquity-dominated spectra very similar to that shown in Figure 5 from time series analysis of radiolarian assemblages at two northwest Pacific pelagic sites.

If the temperature anomalies that we infer at Santa Barbara Basin are reproduced by $\mathrm{U}_{37}$ profiles at other sites along the California margin, then they imply a larger sensitivity of the North Pacific heat transport system to obliquity forcing than seen at study locations in the North Atlantic and equatorial Pacific oceans. There is no reason to believe that SST patterns must be the same everywhere; indeed, Ruddiman and McIntyre (1984) document progressive latitudinal changes in the weight of precessional and obliquity influences on SST as inferred from planktonic assemblages in the North Atlantic. Imbrie et al. (1992) propose a paradigm whereby the response of a host of oceanographic variables to ice age orbital forcing are seen as a set of variations whose amplitude and phasing vary regionally. Alkenone unsaturation indices from Santa Barbara Basin suggest that North Pacific SST variations respond in a distinctly different manner to orbital rhythms than do those of other parts of the world ocean.

\section{ACKNOWLEDGMENTS}

Portions of this work were funded by the INCOR climate group of the University of California, and by NOAA. We thank Julie
Kennedy for help in teaching us alkenone extraction procedures, Mark McCaffrey and David Williams for advice on silica gel column chromatography, and Arndt Schimmelmann and Simon Brassell at Indiana University for GC/MS analyses. Julie Kennedy and Fred Prahl provided helpful reviews of our manuscript.

\section{REFERENCES}

Brassell, S.C., Eglinton, G., Marlowe, I.T., Pflaumann, U., and Sarnthein. M., 1986. Molecular stratigraphy: a new tool for climatic assessment. Nature, 320:129-133.

Broecker, W.S., Andree, M., Wölfli, W., Oeschger, H., Bonani, G., Kennett, J.P., and Peteet, D., 1988. The chronology of the last deglaciation: implications to the cause of the Younger Dryas event. Paleoceanography, 3:119.

CLIMAP Project Members, 1976. Glacial North Atlantic 18,000 years ago: a CLIMAP reconstruction. In Investigation of Late Quaternary Paleoceanography and Paleoclimatology. Mem.-Geol. Soc. Am., 145:43-76.

1981. Seasonal reconstructions of the Earth's surface at the last glacial maximum. Geol. Soc. Am., Map and Chart Ser., MC36.

Conte, M.H.. and Eglinton, G., 1993. Alkenones and alkenoate distributions within the euphotic zone of the eastern North Atlantic: correlation with production temperature. Deep-Sea Res., 40:1935-1961.

Conte, M.H., Eglinton, G., and Madureira, L.A.S., 1992. Long-chain alkenones and alkyl alkenoates as palaeotemperature indicators: their production. flux and early sedimentary diagenesis in the eastern North Atlantic. Org. Geochem., 19:287-298.

Eglinton, G., Bradshaw, S.A., Rosell, A., Sarnthein, M., Pflaumann, U., and Tiedemann, R., 1992. Molecular record of secular sea surface temperature changes on 100-year timescales for glacial terminations I, II, and IV Nature, 356:423-426.

Farrimond, P., Poynter, J.G., and Eglinton, G., 1990. A molecular stratigraphic study of Peru Margin sediments, Hole 686B, Leg 112. In Suess, E., von Huene, R., et al., Proc. ODP. Sci. Results, 112: College Station, TX (Ocean Drilling Program), 547-553.

Hays, J.D., Imbrie, J., and Shackleton, N.J., 1976. Variations in the earth's orbit: pacemaker of the Ice Ages. Science, 194:1121-1132.

Imbrie, J., Boyle, E.A., Clemens, S.C., Duffy, A., Howard, W.R., Kukla, G. Kutzbach, J., Martinson, D.G., McIntyre, A., Mix, A.C., Molfino, B. Morley, J.J., Peterson, L.C., Pisias, N.G., Prell. W.L., Raymo, M.E., Shackleton. N.J., and Toggweiler, J.R., 1992. On the structure and origin of major glaciation cycles, 1. Linear responses to Milankovitch forcing. Paleoceanography, 7:701-738.

Imbrie, J., Hays, J.D., Martinson, D.G.. McIntyre, A., Mix, A.C., Morley, J.J., Pisias, N.G., Prell, W.L., and Shackleton, N.J., 1984. The orbital theory of Pleistocene climate: support from a revised chronology of the marine $\delta^{i n} \mathrm{O}$ record. In Berger, A., Imbrie, J., Hays, J., Kukla, G., and Saltzman, B. (Eds.), Milankovitch and Climate (Pt. 1): Dordrecht (D. Reidel), 269-305.

Imbrie, J., and Kipp, N.G., 1971. A new micropaleontological method for quantitative paleoclimatology: application to a late Pleistocene Caribbean core. In Turekian, K.K. (Ed.), The Late Cenozoic Glacial Ages: New Haven, CT (Yale Univ. Press), 71-181.

Jasper, J., and Gagosian, R.B., 1989. Alkenone molecular stratigraphy in an oceanic environment affected by glacial freshwater events. Paleoceanography, 4:603-614.

Kennedy, J.A., 1992. Molecular stratigraphic evaluation of twentieth century El Niño events and plankton productivity in the Santa Barbara Basin. California, and the Guaymas Basin. Mexico [Ph.D. thesis]. Stanford Univ., Stanford, CA.

Kennedy, J.A., and Brassell, S.C., 1992. Molecular records of twentieth century El Niño events in laminated sediments from the Santa Barbara basin. Nature, 357:62-64.

Lehman. S.J., Weicker, N., and Eglinton, T.J., 1991. Surface-most temperature changes of the subtropical Atlantic during the last deglaciation. Eos, $73: 259$.

Lyle, M.W., Prahl, F.G., and Sparrow. M.A., 1992. Upwelling and productivity changes inferred from a temperature record in the central equatorial Pacific. Nature, 355:812-814.

Lynn, R.J., and Simpson, J.J., 1987. The California Current system: the seasonal variability of its physical characteristics. J. Geophys. Res. 92:12947-12966. 
Marlowe, I.T., Brassell, S.C., Eglinton, G., and Green, J.C., 1984. Longchain unsaturated ketones and esters in living algae and marine sediments. Org. Geochem., 6:135-141.

McCaffrey. M.A., 1990. Sedimentary lipids as indicators of depositional conditions in the coastal Peruvian upwelling regime [Ph.D. thesis]. MIT/ WHOI, Woods Hole, MA.

Moore, T.C., Jr., Burckle, L.H.. Geitzenauer, K., Luz. B., Molina-Cruz. A., Robertson, J.H., Sachs, H., Sancetta, C., Thiede, J., Thompson. P.. and Wenkam, C., 1980. The reconstruction of sea surface temperatures in the Pacific Ocean of 18,000 BP. Mar. Micropaleontol., 5:215-247.

Morley, J.J., Pisias, N.G., and Leinen. M., 1987. Late Pleistocene time series of atmospheric and oceanic variables recorded in sediments from the subarctic Pacific. Paleoceanography, 2:49-62.

Pares-Sierra, A., and O'Brien, J.J., 1989. The seasonal and interannual variability of the California Current system: a numerical model. J. Geophys. Res., 94:3159-3180.

Pisias, N.G., 1978. Paleoceanography of the Santa Barbara Basin during the last 8000 years. Quat. Res., 10:366-384.

Poynter, J.G., Farrimond, P., Brassell, S.C., and Eglinton, G., 1989. Molecular stratigraphic study of sediments from Holes 658A and 660A. Leg 108. In Ruddiman, W., Sarnthein, M., et al., Proc: ODP. Sci. Results, 108: College Station. TX (Ocean Drilling Program). 387-394.

Prahl, F.G., Collier, R.B., Dymond, J., Lyle, M., and Sparrow, M.A., 1993. A biomarker perspective on prymnesiophyte productivity in the northeast Pacific Ocean. Deep-Sea Res. Part A, 40:2061-2076.

Prahl, F.G., de Lange. G.J., Lyle, M., and Sparrow, M.A., 1989a. Post-depositional stability of long-chain alkenones under contrasting redox conditions. Nature, 341:434-437.

Prahl, F.G., Muehlhausen, L.A., and Lyle, M., 1989b. An organic geochemical assessment of oceanographic conditions at MANOP Site C over the past 26,000 years. Paleoceanography, 4:495-510.

Prahl, F.G., Muehlhausen, L.A., and Zahnle, D.L.. 1988. Further evaluation of long-chain alkenones as indicators of paleoceanographic conditions. Geochim. Cosmochim. Acta, 52:2303-2310.

Prahl, F.G., and Wakeham, S.G., 1987. Calibration of unsaturation patterns in long-chain ketone compositions for paleotemperature assessment. Nature, 330:367-369.
Ruddiman, W.F., and McIntyre, A., 1981. The North Atlantic Ocean during the last deglaciation. Palaeogeogr., Palaeoclimatol., Palaeoecol. $35: 145-214$.

1984. Ice-age thermal response and climatic role of the surface Atlantic Ocean, $40^{\circ} \mathrm{N}$ to $63^{\circ} \mathrm{N}$. Geol. Soc. Am. Bull., 95:381-396.

Schneider, R.R., Müller, P.J., and Ruhland, G., 1995. Late Quaternary surface circulation in the east equatorial south Atlantic: evidence from alkenone sea surface temperatures. Paleoceanography, 10:197-220.

Shackleton. N., 1967. Oxygen isotope analyses and Pleistocene temperatures re-assessed. Nature, 215:15-17.

Sikes, E.L., and Volkman. J.K.. 1993. Calibration of alkenone unsaturation ratios $\left(\mathrm{U}^{\mathrm{k}}{ }_{17}\right)$ for paleotemperature estimation in cold polar waters. Geochim. Cosmochim. Acta. 57:1883-1889.

Simpson, J.J., 1983. Large-scale thermal anomalies in the California Current during the 1982-1983 El Niño. Geophys. Res. Lett., I0:937-940.

Sun, M.-Y., and Wakeham, S.G., 1994. Molecular evidence for degradation and preservation of organic matter in the anoxic Black Sea Basin. Geochim. Cosmochim. Acta, 58:3395-3406.

Thompson, P.R., 1981. Planktonic foraminifera in the western North Pacific during the past 150,000 years: comparison of modern and fossil assemblages. Palaeogeogr., Palaeoclimatol., Palaeoecol., 35:241-279.

Thomson, D.J., 1985. Spectrum estimation and harmonic analysis. Proc. IEEE, 70:1055-1096.

Volkman, J.K., Eglinton, G., Corner, E.D.S., and Sargent, J.R., 1980. Novel unsaturated straight-chain $\mathrm{C}_{37-} \mathrm{C}_{34}$ methyl and ethyl ketones in marine sediments and a coccolithophore Emiliania huxleyi. In Douglas, A.G.. and Maxwell, J.R. (Eds.), Advances in Organic Geochemistry 1979: Oxford (Pergamon Press), 219-228.

Date of initial receipt: 6 September 1994

Date of acceptance: 13 February 1995

Ms 146SR-301 